\title{
PENGEMBANGAN NILAI-NILAI BUDAYA SEKOLAH BERKARAKTER
}

\author{
Naniek Sulistya Wardani \\ wardani.naniek@gmail.com \\ Pendidikan Guru Sekolah Dasar - FKIP - UKSW - Salatiga
}

\begin{abstract}
ABSTRAK
Tujuan dari penelitian ini adalah: 1) untuk mengetahui nilai-nilai budaya apa sajakah yang berkembang di SD Negeri Blotongan 3 Salatiga; 2) untuk mengetahui karakteristik nilai budaya berkarakter yang berkembang di SD Negeri Blotongan 3 Salatiga; 3) mengetahui pola pendidikan budaya karakter yang telah diterapkan, dan 4) menemukan pola pendidikan nilai budaya yang efektif di SD Negeri Blotongan 3 Salatiga. Jenis penelitian ini adalah penelitian deskriptif. Subyek penelitian yakni siswa SD Negeri Blotongan 3 Salatiga. Teknik pengumpul-an data melalui observasi dan angket. Teknik analisis data menggunakan teknik persentase. Hasil penelitian menunjukkan bahwa: 1) Nilainilai budaya berkembang di sekolah melalui: a) simbol-simbol tertulis seperti: Visi sekolah, pajangan penuntun berperilaku, dan slogan pesan; b) Sikap siswa berupa tingkat kedisiplinan mengikuti pelajaran mencapai $100 \%$, kesehatan 97,04 \% (164 dari 169 siswa), keberbersihan; kecerdasan yang ditunjukkan oleh tingkat kelulusan siswa selama 3 tahun mencapai $100 \%$ dan tingkat kenaikan kelas 97,40\% (dari keseluruhan 192 siswa); keterampilan siswa unggul dalam bermain drum band; berbudi luhur dalam bertutur kata dan kejujuran; bertaqwa kepada Tuhan melalui pelajaran agama, upacara bendera dan kegiatan pengajian bersama; c) Kepercayaan yang tertanam ditunjukkan oleh kepercayaan orang tua dan siswa kepada sekolah; 2) Karakteristik nilai budaya berkarakter yang berkembang di sekolah meliputi nilai kesopanan, nilai kepedulian terhadap sesama dan nilai kerjasama mencapai 84,22\%, 87,52\% dan 84,81\%; 3) Pola pendidikan budaya karakter mengikuti pendekatan komunikasi persuasif, pendekatan kontak pribadi dan pendekatan bermain peran berturut-turut sebesar 84,61\%; 84,02\% dan 65,68\%; 4) Pola Pendidikan Nilai Budaya terlaksana dengan efektif melalui membiasakan bertingkah laku, pemberian contoh dan penciptaan suasana harmonis.
\end{abstract}

Kata kunci: nilai-nilai budaya sekolah; karakteristik nilai budaya berkarakter, pola pendidikan budaya karakter; dan pola pendidikan nilai budaya. 


\section{PENDAHULUAN}

Kompetensi lulusan siswa SD dalam Kurikulum 2013 menyatakan bahwa menjadi pribadi yang beriman, berakhlak mulia, percaya diri dan bertanggung jawab dalam berinteraksi secara efektif dengan lingkungan sosial, alam sekitar, serta dunia, dan peradabannya. (Peraturan Menteri Pendidikan dan Kebudayaan No. 67 Tahun 2013 tentang Kerangka Dasar dan Struktur Kurikulum SD/MI). Kompetensi lulusan yang pertama dalam taksonomi Bloom termasuk aspek sikap. Untuk mencapai kompetensi sikap, maka dalam kompetesi inti terdiri dari sikap religius dan sikap sosial. Sikap religius, kompetensi intinya adalah 'Menerima dan menjalankan ajaran agama yang dianutnya', sedangkan sikap sosial, kompetensinya adalah 'Memiliki perilaku jujur, disiplin, tanggung jawab, santun, peduli, dan percaya diri dalam berinteraksi dengan keluarga, teman, dan guru'. Ke dua sikap ini tidak termasuk dalam satu mata pelajaran tertentu, namun dicapai melalui sikap siswa sehari-hari melalui semua pembelajaran yang diberikan. Sikap merupakan suatu bentuk respon/tanggapan yang cenderung konsisten memberikan tanggapan senang atau tidak senang terhadap suatu objek. Perwujudan respon ini merupakan hasil belajar, bukan pembawaan seseorang atau karena keturunan dari orang tuanya.

Triandis (1971) mengatakan bahwa sikap sebagai suatu pendapat disertai perasaan yang menentukan tindakan terhadap suatu objek. Dengan demikian komponen sikap itu meliputi (1). Kognitif aspek pengetahuan tentang objek; (2) Afektif perasaan positif atau negatif yang berkaitan dengan pengetahuan yang dimiliki; (3) Tingkah laku perwujudan dalam bentuk tindakan thd suatu objek. Jadi sikap itu, dapat dipelajari melalui pembelajaran di kelas. Pendekatan yang dapat dipergunakan dalam memperbaiki dan membentuk sikap siswa adalah (1). Pendekatan komunikasi persuasif dengan pemberian informasi tentang sesuatu disertai dengan ajakan, himbauan, anjuran bersikap positif; (2). Pendekatan kontak pribadi orang normal diajak bergaul, bermain, belajar bersama; (3). Pendekatan bermain peran dengan meminta siswa untuk merasakan atau mengalami sebagai orang cacat, dengan berperan sebagai tunanetra, tunarungu, dan sebagainya. Melalui pembelajaran, maka sikap siswa akan terbentuk. Sikap akan membentuk kepribadian seseorang, dan kepribadian tidak dapat terbentuk secara berdiri sendiri.

Melalui sikap dalam pembelajaran untuk menerima, menjalankan, menghargai, menghayati dan mengamalkan, ada proses yang dilakukan siswa melalui olah pikir (pengetahuan) siswa secara nalar, siswa perlu mengetahui sesuatu yang terkait dengan substansi yang dipelajarinya, setelah siswa tahu tentang pengetahuan, maka siswa akan membedakan pengetahuan itu, lalu melalui oleh pikirnya, siswa akan mengimplementasikannya, melakukan analisis, melakukan evaluasi, melalui hasil evaluasi siswa akan mencari dan menemukan solusi. Apa yang dilakukan siswa melalui oleh pikir atau pengetahuan ini, akan terwujud dalam 
sikapnya sehari-hari dan sikap ini akan dipengaruhi oleh kompetensi keterampilannya.

Kompetensi ketrampilan siswa yang dicapai melalui struktur kurikulum adalah kompetensi mengamati, menanya, mencoba, mengolah, menyaji, menalar, dan mencipta. Dengan demikian, kompetensi yang dimiliki siswa menjadi utuh, seperti yang dikehendaki dalam taksonomi Bloom yakni mencakup aspek sikap, pengetahuan dan ketrampilan. Di samping itu, sikap siswa di sekolah dapat diajarkan melalui cara: Memberi contoh, teladan atau model peran. Setiap individu belajar dari seperangkat contoh melaui perilaku orang lain yang diterimanya, Membujuk atau meyakinkan. Membujuk atau meyakinkan seseorang mempunyi dasar kognitif. Hal ini tidak terkait dengan aspek emosional dari perilaku seseorang. Mengajarkan melalui budaya.

Budaya dan agama mempengaruhi perilaku seseorang tanpa pilihan. Setiap individu dapat menerima keyakinan tersebut dengan pilihan terbatas. Perilaku seseorang dikontrol dengan membatasi pilihan seseorang dengan tidak mempunyai pilihan secara bebas menetapkan peraturan-peraturan. Ketentuan dan peraturan yang digunakan untuk mengontrol perilaku seseorang adalah: (1) Perilaku yang dipelajari biasanya dapat diterima secara sosial dan diterapkan dalam situasi yang sama dengan waktu yang akan datang; (2) Berperilaku dalam cara tertentu karena takut diberi sanksi, sehingga tidak mempertimbangkan nilai benar atau salah; (3) Menggunakan nilai untuk mengarahkan perilakunya, berarti dapat membedakan baik dan buruk, benar atau salah; (4) Mempertimbangkan dengan hati nurani. Orang sering mempelajari seperangkat norma perilaku yang dianggap benar. Kegagalan untuk Mengikuti norma (hati nurani) dapat mengakibatkan perasaan bersalah. Budaya tersebut perlu dikembangkan di sekolah dan nampak melalui sikap siswa dallam kehidupan sehari-hari di sekolah. Dengan demikian penanaman nilainilai budaya ini menjadi penting.

Nilai-nilai budaya merupakan nilai- nilai yang disepakati dan tertanam dalam suatu masyarakat, lingkup organisasi, lingkungan masyarakat, yang mengakar pada suatu kebiasaan, kepercayaan (believe), simbol-simbol, dengan karakteristik tertentu yang dapat dibedakan satu dan lainnya sebagai acuan perilaku dan tanggapan atas apa yang akan terjadi atau sedang terjadi. (Ardian, 2013). Nilainilai budaya akan tampak pada simbol-simbol, slogan, moto, visi misi, atau sesuatu yang nampak sebagai acuan pokok motto suatu lingkungan atau organisasi. Ada tiga hal yang terkait dengan nilai-nilai budaya yaitu (1). Simbol-simbol, slogan atau yang lainnya yang kelihatan kasat mata (jelas); (2) Sikap, tindak laku, gerak gerik yang muncul akibat slogan, moto tersebut; dan (3) Kepercayaan yang tertanam (believe system) yang mengakar dan menjadi kerangka acuan dalam bertindak dan berperilaku (tidak terlihat). Nilai-nilai budaya yang berlaku di sekolah ini, akan membentuk sistem budaya yang merupakan tingkatan tingkat yang paling tinggi dan 
abstrak dalam adat istiadat. Hal itu disebabkan karena nilai - nilai budaya itu merupakan konsep - konsep mengenai apa yang hidup dalam alam pikiran sebagian besar dari warga suatu masyarakat mengenai apa yang mereka anggap bernilai, berharga, dan penting dalam hidup, sehingga dapat berfungsi sebagai suatu pedoman yang memberi arah dan orientasi kepada kehidupan para warga masyarakat itu sendiri. Nilai - nilai budaya ini bersifat umum, luas dan tak konkret, maka nilai-nilai budaya dalam suatu kebudayaan tidak dapat diganti dengan nilainilai budaya yang lain dalam waktu yang singkat.

Dalam masyarakat ada sejumlah nilai budaya yang satu dan yang lain berkaitan satu sama lain sehingga merupakan suatu sistem, dan sistem itu sebagai suatu pedoman dari konsep - konsep ideal dalam kebudayaan memberi pendorong yang kuat terhadap arah kehidupan masyarakat. Menurut Koentjaraningrat (1987: 85),nilaibudayaterdiridarikonsepsikonsepsi yang hidup dalam alam pikiran seba gian besar warga masyarakat mengenai hal - hal yang mereka anggap amat mulia. Sistem nilai yang ada dalam suatu masyarakat dijadikan orientasi dan rujukan dalam bertindak. Oleh karena itu, nilai budaya yang dimiliki seseorang mempengaruhinya dalam menentukan alternatif, cara - cara, alat - alat, dan tujuan - tujuan pembuatan yang tersedia. Sedangkan Lyde Kluckhohn dalam Pelly (1994) mendefinisikan nilai budaya sebagai konsepsi umum yang terorganisasi, yang mempengaruhi perilaku yang berhubungan dengan alam, kedudukan manusia dalam alam, hubungan orang dengan orang dan tentang hal - hal yang diingini dan tidak diingini yang mungkin bertalian dengan hubungan orang dengan lingkungan dan sesama manusia.

Dan Sumaatmadja dalam Marpaung (2000) mengatakan bahwa pada perkembangan, pengembangan, penerapan budaya dalam kehidupan, berkemban g pula nilai - nilai yang melekat di masyarakat yang mengatur keserasian, keselarasan, serta keseimbangan. Nilai tersebut dikonsepsikan sebagai nilai budaya. Selanjutnya, bertitik tolak dari pendapat diatas, maka dapat dikatakan bahwa setiap individu dalam melaksanakan aktivitas sosialnya selalu berdasarkan serta berpedoman kepada nilai - nilai atau sistem nilai yang ada dan hidup dalam masyarakat itu sendiri. Artinya nilai - nilai itu sangat banyak mempengaruhi tindakan dan perilaku manusia, baik secara individual, kelompok atau masyarakat secara keseluruhan tentang baik buruk, benar salah, patut atau tidak patut.

SD Negeri Blotongan 3 Salatiga adalah salah satu SD di Salatiga yang terletak di batas pinggir Kota Salatiga dan boleh dikatakan sekolah yang berada di daerah 'pedesaan'. Sekolah ini merupakan sekolah yang memiliki siswa kelas 1- 6 sebanyak 169 siswa dan siswa yang berkebutuhan khusus (inklusi) sebanyak 21 siswa, dan siswa lainnya yang normal. Sekolah ini merupakan sekolah yang 'guyub' (kompak secara sosial), hubungan antar siswa, guru dan orang tua nampak akrab, dan adanya acara pengajian bersama di sekolah. Kehidupan sehari-hari di sekolah antara siswa, guru dan kepala sekolah serta perangkat sekolah seperti tukang kebon, 
penjual makanan nampak akrab. Kehidupan sekolah yang harmonis terjadi di SD Negeri Blotongan 3 dengan aktivitas-aktivitas berprestasi seperti juara drum band yang terus menerus. Karakter kepribadian sekolah yang nampak dalam bentuk kerjasama dalam pembelajaran, kemandirian siswa dalam mengerjakan tugas-tugas sekolah, sikap menghormati teman yang sedang berbicara, sikap menghormati tamu yang datang dan nampak dalam sikap tanggung jawab siswa dalam menjalankan tugas-tugas sekolah melalui tugas diskusi, tugas pekerjaan sekolah maupun dalam aktivitas ekstrakurikuler. Kondisi inilah yang menarik untuk diteliti dengan judul pengembangan nilai-nilai budaya sekolah yang berkarakter.

Tujuan dari penelitian ini adalah (1) untuk mengetahui nilai-nilai budaya apa sajakah yang berkembang di SD Negeri Blotongan 3 Salatiga; (2) untuk mengetahui karakteristik nilai budaya berkarakter yang berkembang di SD Negeri Blotongan 3 Salatiga; (3) mengetahui pola pendidikan budaya karakter yang telah diterapkan, dan (4) menemukan pola pendidikan nilai budaya yang efektif di SD Negeri Blotongan 3 Salatiga.

\section{METODE PENELITIAN}

Jenis penelitian ini adalah penelitian deskriptif. Subyek penelitian yakni siswa SD Negeri Blotongan 3 Salatiga. Teknik pengumpulan data melalui observasi dan angket berupa skala sikap. Variabel penelitian adalah nilai-nilai budaya sekolah, karakteristik nilai budaya berkarakter, pola pendidikan budaya karakter; dan efektifitas pola pendidikan nilai budaya. Teknik analisis data menggunakan teknik persentase.

\section{HASIL DAN PEMBAHASAN}

Hasil penelitian tentang nilai-nilai budaya berkarakter di SD Negeri Blotongan 3 Salatiga ditunjukkan oleh nilai-nilai budaya yang ada di sekolah, karakteristik nilai budaya yang berkarakter di sekolah, pola pendidikan budaya karakter yang diterapkan di sekolah dan efektifitas pola pendidikan nilai budaya yang ada

\section{a. Nilai-nilai budaya sekolah.}

Nilai - nilai budaya yang berkembang di sekolah merupakan konsep konsep yang hidup di SD Negeri Blotongan 3 mengenai hal-hal yang bernilai, berharga, dan penting yang menjadi pedoman berperilaku dengan alam dan sesama untuk mengatur keserasian, keselarasan, serta keseimbangan. Oleh karena itu, setiap individu di sekolah dalam dalam bertingkah laku selalu berdasarkan serta berpedoman kepada nilai - nilai yang hidup di sekolah itu sendiri. Dengan demikian, nilai - nilai itu akan mempengaruhi tindakan dan perilaku seseorang, baik secara individual maupun kelompok secara keseluruhan 
tentang baik buruk, benar salah, patut atau tidak patut.Nilai-nilai itu berfungsi sebagai suatu pedoman yang memberi arah dan orientasi kepada kehidupan para warga sekolah dasar Negeri Blotongan 3 Salatiga.

Nilai-nilai budaya yang berkembang di sekolah nampak melalui: (1). Simbol-simbol atau slogan yang tertulis di dinding sekolah atau di pasang tergantung di ruang kelas, di ruang perpustakaan. Slogan yang nampak dan dipasang di sekolah adalah (a). Visi sekolah yang merupakan cita-cita sekolah yang ingin dicapai, (b) pajangan yang terkait dengan penuntun berperilaku warga sekolah yakni dasa darma Pramuka; dwisatya dan trisatya Pramuka; (c) slogan yang berupa pesan yakni jagalah kebersihan, kebersihan itu sebagian dari iman; rajin pangkal pandai. Slogan atau simbol tersebut merupakan pesan dan pedoman yang dilakukan dalam berperilaku di sekolah, sehingga setiap warga sekolah harus melaksanakannya. Visi sekolah yakni 'terwujudnya siswa yang disiplin, cerdas, terampil, berbudi luhur dan bertaqwa kepada Tuhan Yang Maha Esa'.Visi ini dapat dibaca oleh siapa saja yang menginginkan untuk membacanya, karena visi tersebut di pasang di sekolah baik di ruang guru maupun di ruang-ruang kelas, sehingga dengan mau membaca visi tersebut, maka setiap siswa yang membaca dapat mendorong dan menyemangati siswa untuk berbuat disiplin dalam setiap tindakan, untuk cerdas dalam berpikir, untuk terampil melakukan sesuatu, berbudi luhur dan bertaqwa kepada Tuhan Yang Maha Esa sesuai dengan agamanya masing-masing'. Mendasarkan dari visi yang dicanangkan di sekolah, nampak sikap yang dimiliki oleh siswa. (2) Sikap siswa yang muncul dari visi sekolah yang pertama, nampak pada kedisiplinan siswa dalam mengikuti pelajaran, yang disajikan melalui tabel 1 di bawah ini.

Tabel 1

Kedisiplinan Mengikuti Pelajaran Rata-Rata Per Minggu

\begin{tabular}{|l|l|l|}
\hline \multicolumn{1}{|c|}{ Kedisiplinan } & \multicolumn{1}{c|}{ Frek } & \multicolumn{1}{c|}{$\%$} \\
\hline 1. Masuk sekolah & 163 & 96,45 \\
\hline 2. Sakit & 5 & 2,96 \\
\hline 3. Ijin & 1 & 0,59 \\
\hline Jumlah & 169 & 100 \\
\hline
\end{tabular}

Nampak bahwa kedisiplinan siswa dapat mencapai $100 \%$, karena siswa yang tidak masuk sekolah juga memberi keterangan, apakah yang bersangkutan sakit atau ijin. Di samping itu, nampak bahwa kesehatan siswa baik, hal ini nampak rata-rata mingguan siswa yang sakit hanya mencapai 2,96 \% (5 dari 169 siswa), begitu pula siswa yang terpaksa ijin tidak mengikuti pelajaran di sekolah, hanya di bawah $1 \%$ yakni $0,59 \%$ (1 dari 169 siswa). Kesehatan warga sekolah 
ini mengindikasikan bahwa lingkungan yang ada di sekolah adalah bersih baik kebersihan di dalam sekolah, kebersihan di halaman dan di sekitar sekolah maupun kebersihan pada kantin sekolah. Hal ini merupakan ujud perilaku warga sekolah yang telah dihimbau melalui slogan kebersihan yang diberikan oleh sekolah. Visi sekolah yang ke 2 terkait dengan kecerdasan. Kecerdasan siswa ditunjukkan oleh tingkat kelulusan siswa selama 3 tahun terakhir yakni 2011/2012; 2012/2013; dan 2013/2014 mencapai 100 \%. Persentase ini sebagai bukti bahwa sekolah berupaya secara maksimal untuk mencapai visi yang telah dicanangkan melalui mencerdaskan siswanya. Di samping itu, persentase yang sangat rendah yakni 2,6\% (5 siswa dari 192 siswa) untuk siswa yang tidak naik kelas, meskipun sekolah ini memiliki siswa inklusi, hal ini terjadi karena guru dengan iklas memberi semangat kepada siswa siswinya dan selalu berkoordinasi dengan orang tua siswa, upaya guru dan kepala sekolah untuk mencapai visi. Visi yang ketiga, nampak melalui keterampilan siswa dalam bermain drum band. Setiap latihan yang dilakukan, seluruh siswa yang terlibat selalu hadir dan nampak hasilnya, bahwa drum band SD Negeri Blotongan 3 selalu sukses dan berhasil menjuarai setiap perlombaan yang dilakukan di Kota Salatiga.

Sikap siswa yang mendukung visi ke 4 yakni berbudi luhur. Nampak dalam pergaulan dengan sesama siswa dan siswa dengan guru serta siswa dengan praktikan, selalu menggunakan bahasa yang baik, tidak terdengar kata-kata jorok, kata-kata kotor. Terkait dengan kejujuran, nampak ketika siswa jajan di kantin, siswa selalu membayar jajanan sebagaimana mestinya. Kesopanan dalam berbicara dan kejujuran dalam membeli barang, menampakkan bahwa siswa itu berbudi luhur. Dalam melaksanakan visi sekolah yang ke 5 yaitu bertaqwa kepada Tuhan Yang Maha Esa, sekolah memberikan pelajaran agama melalui jam pelajaran, melalui upacara bendera dan kegiatan pengajian bersama (siswa, guru dan kepala sekolah) setiap bulan sekali. Hal ini menampakkan ketaqwaannya kepada Tuhan Yang Maha Esa.

Sejumlah nilai budaya tersebut (kedisiplinan, kebersihan, kecerdasan, ketrampilan, berbudi luhur, dan ketaqwaan, satu dan yang lain berkaitan sehingga merupakan suatu sistem, dan sistem inilah yang menjadi pedoman dari konsep-konsep ideal dalam kebudayaan yang mendorong dengan kuat dalam kehidupan warga sekolah. Sistem nilai yang ada ini dijadikan orientasi dan rujukan dalam bertindak. (3) Kepercayaan yang tertanam (believe system) yang telah mengakar, menjadi kerangka acuan dalam bertindak dan berperilaku. Aktivitas ini tidak terlihat atau tidak kasat mata seperti slogan atau simbol. Kepercayaan yang berkembang di SD Negeri Blotongan 3 Salatiga nampak pada kepercayaan dari orang tua yang tinggi kepada sekolah baik melalui kepala sekolah dan guru. Di samping itu, kepercayaan siswa kepada guru dan kepala 
sekolah nampak pada hubungan nya yang selalu mendekat kepada guru dan kepala sekolah.

\section{b. Karakteristik nilai budaya berkarakter}

Karakteristik nilai budaya berkarakter yang berkembang di SD Negeri Blotongan 3 Salatiga meliputi nilai kesopanan, kepedulian, kerjasama. Nilai kesopanan yang nampak disajikan melalui tabel 2 di bawah ini.

Tabel 2

Distribusi Nilai Kesopanan berdasarkan

Pernyataan sikap

\begin{tabular}{|l|c|c|c|c|c|}
\hline \multicolumn{1}{|c|}{ Kesopanan } & SS & S & TS & STS & Jml \\
\hline 1. Mengucapkan salam & 99 & 34 & 10 & 16 & 169 \\
\hline 2. Berjabat Tangan & 101 & 45 & 10 & 13 & 169 \\
\hline 3. Berpakaian rapi & 98 & 39 & 22 & 10 & 169 \\
\hline
\end{tabular}

Keterangan:

1. Sangat setuju (SS)

2. Setuju (S)

3. Tidak setuju (TS)

4. Sangat tidak setuju (STS)

Mendasarkan tabel 2, nampak bahwa hampir seluruh siswa telah melaksanakan nilai-nilai kesopanan dengan baik, 13,8 \% saja yang tidak setuju dengan mengucapkan salam, $13,60 \%$ tidak berjabat tangan dan 18,93\% yang tidak berpakaian rapi. Mendasarkan pada persentase yang diperoleh, maka sebagian besar siswa telah memiliki nilai-nilai kesopanan. Adapun nilai kepedulian siswa ditunjukkan melalui tabel 3 berikut ini.

Tabel 3

Distribusi Nilai Kepedulian berdasarkan

Pernyataan sikap

\begin{tabular}{|l|c|c|c|c|c|}
\hline \multicolumn{1}{|c|}{ Kepedulian } & SS & S & TS & STS & Jml \\
\hline 1. Menolong sesama & 86 & 59 & 14 & 10 & 169 \\
\hline 2. Menengok teman sakit & 75 & 74 & 11 & 9 & 169 \\
\hline 3. Membersihkan kelas & 79 & 83 & 3 & 4 & 169 \\
\hline
\end{tabular}

Nilai kepedulian siswa SD Blotongan 3 nampak pada, pernyataannya dalam menolong sesama, menengok teman sakit dan membersihkan kelas sebesar $78,70 \% ; 88,17 \%$ dan 95,68\%. Hal ini nampak bahwa hanya dibawah $20 \%$ saja 
yang siswa tidak mempunyai kepedulian dengan sesama, meskipun demikian siswa memiliki kepedulian dengan persentase yang rendah. Demikian juga nilai kerjaama siswa, nampak pada tabel 4 berikut.

\section{Tabel 4}

Distribusi Nilai Kerjasama berdasarkan Pernyataan sikap

\begin{tabular}{|l|c|c|c|c|c|}
\hline \multicolumn{1}{|c|}{ Kerjasama } & SS & S & TS & STS & Jml \\
\hline 1. Diskusi pemecahan masalah & 85 & 58 & 16 & 10 & 169 \\
\hline 2. Koordinasi dalam melaksanakan tugas & 89 & 59 & 11 & 10 & 169 \\
\hline 3. Berpakaian rapi & 82 & 57 & 16 & 14 & 169 \\
\hline
\end{tabular}

Mendasarkan tabel 4, nampak bahwa siswa SD Negeri Blotongan 3 Salatiga memiliki kerjasama dalam diskusi memecahkan permasalahan, koordinasi dalam melaksanakan tugas dan berpakaian rapi sebesar 84,62\%; 87,57 \% dan 82,25\%. Persentase yang tinggi dalam berperilaku, yang menunjukkan karakteristik nilai budaya yang berkembang di sekolah

\section{c. Pola pendidikan budaya karakter.}

Nilai budaya yang berkembang di sekolah SD Negeri Blotongan 3 Salatiga, menjadi pertimbangan sekolah untuk menentukan cara mendidik siswasiswanya dalam rangka mencapai kompetensi kelulusan dan visi sekolah. Oleh karena itu, pendekatan pendidikan budaya berkarakter yang sesuai dengan karakteristik siswa, capaian kompetensi peserta didik dan visi yang diharapkan, menjadi penting. Hasil penelitian menunjukkan bahwa, ada 3 pendekatan pendidikan budaya berkarakter yang dipergunakan sekolah yakni (a) pendekatan komunikasi persuasif melalui ajakan dan himbauan, (b) pendekatan melalui kontak pribadi dengan bergaul dengan siswa, bermain dan membimbing belajar bersama dan (c) pendekatan bermain peran.

Berbagai pendekatan di atas dikembangkan di sekolah, agar siswasiswinya dapat mencapai kompetensi dan visi yang diharapkan dengan memiliki perilaku yang telah membudaya dan memiliki karakter. Oleh karena itu, pendidikan budaya berkarakter nampak diterapkan di sekolah dan ditunjukkan melalui Tabel 5. Nampak dari tabel 5, bahwa siswa merasakan ajakan guru untuk berperilaku yang membudaya dan berkarakter baik melalui slogan-slogan yang terpasang di sekolah maupun melalui pendekatan guru melalui kontak langsung dengan siswa, yang ditunjukkan oleh besarnya persentase yakni $84,61 \%$. 


\section{Tabel 5}

Distribusi Pola Pendidikan Budaya Karakter berdasarkan Pernyataan sikap

\begin{tabular}{|l|c|c|c|c|c|}
\hline \multicolumn{1}{|c|}{ Pola Pendidikan } & SS & S & TS & STS & Jml \\
\hline 1. Komunikasi persuasif: ajakan & 87 & 56 & 15 & 11 & 169 \\
\hline $\begin{array}{l}\text { 2. Kontak pribadi: bergaul, } \\
\text { bermain, belajar bersama; }\end{array}$ & 90 & 52 & 13 & 14 & 169 \\
\hline 3. Bermain peran & 60 & 51 & 34 & 24 & 169 \\
\hline
\end{tabular}

Di samping itu, siswa juga merasakan dalam belajar bersama yang dibimbing guru, bermain bersama dengan guru ketika beristirahat maupun melalui pembelajaran di kelas dan ketika pelajaran belum dimulai menunjukkan persentase yang tinggi yakni sebesar 84,02. Namun untuk bermain peran seperti siswa menjadi RA Kartini atau memerankan tokoh lain, tidak banyak dilakukan guru seperti dua pendekatan lainnya, yakni hanya mencapai 65,68\%. Meskipun persentase ini tidak rendah.

\section{d. Efektif Pola Pendidikan Nilai Budaya SD Negeri Blotongan 3 Salatiga}

Hasil penelitian menunjukkan bahwa dalam memberikan pendidikan nilai kepada siswa siswinya sekolah ini sangat efektif. Hal ini nampak bahwa pendidikan nilai yang diberikan tidak secara instan. Namun membiasakan bertingkah laku seperti yang diharapkan, sehingga bagi guru sudah biasa melakukan sikap dan aktivitas yang diharapkan. Jadi tidak ada beban bagi guru dan kepala sekolah karena apa yang dilakukan sudah mengakar dan biasa dilakukan. Hal inilah yang menjadi contoh bagi siswa siswinya untuk bertingkah laku. Di samping menjadikan suasana sekolah yang harmonis berkembang dalam kehidupan sehari-hari. Guru dan kepala sekolah secara bersama-sama telah memberikan contoh dan menjadi teladan bagi siswa-siswinya.

\section{SIMPULAN}

Berdasar hasil penelitian dan pembahasan, maka kesimpulan yang diperoleh adalah:

a. Nilai - nilai budaya yang berkembang di sekolah melalui (1). Simbolsimbol yang tertulis di dinding yakni (a). Visi sekolah, (b) pajangan penuntun berperilaku yakni dasa darma Pramuka; dwisatya dan trisatya Pramuka; (c) slogan yang berupa pesan yakni jagalah kebersihan, kebersihan itu sebagian dari iman; rajin pangkal pandai. (2) Sikap siswa 
berupa kedisiplinan mengikuti pelajaran mencapai $100 \%$, kesehatan yang baik mencapai 97,04 \% (164 dari 169 siswa), bersih; kecerdasan ditunjukkan oleh tingkat kelulusan siswa selama 3 tahun mencapai $100 \%$ dan tingkat kenaikan kelas 97,40\% (5 siswa dari 192 siswa); keterampilan siswa unggul dalam bermain drum band; berbudi luhur yang ditunjukkan dalam bertutur kata dan kejujuran; bertaqwa kepada Tuhan melalui pelajaran agama, upacara bendera dan kegiatan pengajian bersama. (3) Kepercayaan yang tertanam ditunjukkan oleh kepercayaan orang tua kepada sekolah, kepercayaan siswa kepada guru dan kepala sekolah.

b. Karakteristik nilai budaya berkarakter yang berkembang di sekolah meliputi nilai kesopanan, nilai kepedulian terhadap sesama dan nilai kerjasama mencapai $84,22 \%, 87,52 \%$ dan $84,81 \%$.

c. Pola pendidikan budaya berkarakter melalui pendekatan komunikasi persuasif, pendekatan kontak pribadi dan pendekatan bermain peran berturut-turut sebesar $84,61 \% ; 84,02 \%$ dan $65,68 \%$.

d. Pola Pendidikan Nilai Budaya terlaksana dengan efektif melalui membiasakan bertingkah laku, pemberian contoh dan penciptaan suasana harmonis.

\section{DAFTAR ACUAN}

MamanAbdurahman.Tanpa tahun. Teori Sikap. Tersedia di: http://file.upi.edu/ Direktori/FIP/Jur._Pend._Luar_Biasa/195706131985031maman_Abdurahm an_Saepul_R/Sikap.pdf. diunduh 2 Desember 2014.

Syamsudin Amir. 2013. Peraturan Menteri Pendidikan dan Kebudayaan No. 67 Tahun 2013 tentang Kerangka Dasar dan Struktur Kurikulum SD/MI. Jakarta: Berita Negara Republik Indonesia Tahun 2013.

Wirasaputra, G.P. 2011. Nilai Budaya, Sistem Nilai, dan orientasi Nilai Budaya. https://wirasaputra.wordpress.com/2011/10/13/nilai-budaya-sistem-nilaidan-orientasi-nilai-budaya/. Diunduh 2 Desember 2014.

-----. 2013. Pengertian Konsep Nilai dan Sistem.http://adianlangge.blogspot.com/ 2013/05/pengertian-konsep-nilai-dan-sistem.html

Khairil Anwar Notodiputro. 2012. Ujian Nasional: Sarana Untuk Membangun Karakter Bangsa. Proceeding Himpunan Evaluasi Pendidikan Indonesia (HEPI) p. 1-33.

Wardani Naniek Sulistya. 2012. Pengembangan Model Evaluasi Pembelajaran IPS Berbasis Karakter Siswa Kelas V SD. Proceeding Himpunan Evaluasi PendidikanIndonesia(HEPI)p.186-199. 